\title{
PENGENDALIAN MANAJEMEN PUPUK SUBSIDI
}

\author{
Dewi Pratiwi Indriasari \\ STIE-AMKOP Makassar (dewisinaulan01@gmail.com) \\ Amar Sani \\ STIE-AMKOP Makassar
}

\begin{abstract}
ABSTRAK
Pupuk merupakan sarana produksi yang strategis dan sangat berperan penting dalam peningkatan produktivitas dan produksi komoditas pertanian. Sebagai upaya melindungi dan meningkatkan kemampuan petani dalam penerapan pemupukan berimbang, serta meningkatkan ketahanan pangan, pemerintah memberikan subsidi pupuk dengan target petani kecil dan menetapkan Harga Eceran Tertinggi (HET) pupuk bersubsidi.

Tujuan penelitian adalah: untuk penerepan manajemen dalam persediaan pupuk subsidi.

Metode analisis yang digunakan yaitu regresi berganda. Hasil penelitian menunjukkan bahwa variabel perencanaan, pengorganisasian, dan aktivitas mempunyai pengaruh signifikan terhadap pengendalian manajemen. Uji $\mathrm{t}$ diperoleh hasil semakin baik perencanaan, pengorganisasian, dan aktivitas yang diberikan maka semakin baik pula pengendalian manajemen. Uji $\mathrm{F}$ juga diperoleh hasil bahwa perencanaan, pengorganisasian, dan aktivitas signifikan secara simultan terhadap pengendalian manajemen. Sedangkan koefisien determinasi $\mathrm{R}^{2}$ menunjukkan bahwa nilai sangat kuat.
\end{abstract}

Kata Kunci : Perencanaan, Pengorganisasian, Aktivitas dan Pengendalian Manajemen.

\begin{abstract}
Fertilizers are a strategic means of production and play an important role in increasing productivity and production of agricultural commodities. In an effort to protect and improve the ability of farmers to implement balanced fertilization, and improve food security, the government provides fertilizer subsidies with a target of small farmers and sets the highest retail price (HET) of subsidized fertilizer.

The research objectives are: for management management in subsidized fertilizer supplies. The analytical method used is multiple regression. The results of the study show that the planning, organizing, and activity variables have a significant influence on management control. The t test results obtained the better the planning, organizing, and activities provided, the better the management control. Test $F$ also obtained results that planning, organizing, and significant activities simultaneously to management control. While the coefficient of determination $R 2$ indicates that the value is very strong.
\end{abstract}

Keywords: Planning, Organizing, Activities and Management Control.

\section{PENDAHULUAN}

Pupuk Kaltim pastikan stok pupuk urea subsidi bagi petani di Sulawesi Selatan aman. Perusahaan menyiapkan 277 ribu ton pupuk subsidi bagi petani, dengan tingkat 
JURNAL APLIKASI Manajemen \& Kewirausahaan MASS A RO

Volume 1, No. 1, Pebruari 2019

serapan mencapai 77\%. Penyaluran pupuk subsidi dialokasikan melalui Gabungan Kelompok Tani (Gapoktan) sesuai Rencana Definitif Kebutuhan Kelompok (RDKK) berdasarkan persetujuan pemerintah pusat, dengan jumlah kuota berdasarkan pengajuan dari kelompok tani yang disetujui Kementerian Pertanian.

Pupuk bersubsidi diperuntukkan bagi sektor pertanian atau sektor yang berkaitan dengan budidaya tanaman pangan, holtikultura, perkebunan, hijauan pakan ternak, dan budidaya ikan dan/atau udang .

Sasaran pupuk bersubsidi adalah petani, pekebun, dan peternak yang mengusahakan lahan paling luas 2 hektare setiap musim tanam per keluarga petani kecuali pembudidaya ikan dan/atau udang paling luas 1 hektare. Pupuk bersubsidi tidak diperuntukkan bagi perusahaan tanaman pangan, hortikultura, perkebunan, peternakan atau perusahaan perikanan budidaya

Salah satu sarana penunjang peningkatan produksi pertanian yang merupakan kebutuhan strategis petani adalah ketersediaan pupuk di pasar, karena pemanfaatan pupuk langsung dirasakan oleh petani.terutama didalam peningkatan kesejahteraan.oleh karena itu, pengadaan dan penyaluran pupuk diupayakan pengelolaanriya" seefektif dan seefesien mungkin.

Untuk mendukung pengadaan dan penyaluran pupuk secara efektif dan efesien harus menerapkan sistem manajemen.

Nancy W. eder, (2002) menjelaskan bahwa intervensi manajemen keperawatan yang terdiri dari perencanaan, pengorganisasian, koordinasi dan advokasi dalam mengambilan keputusan yang tepat, efisien dan efektif.

Sedangkan Abdu, H. L., Hanan;Bauer, Michael A (2002) , Dengan meningkatnya ketersediaan dan kompleksitas sistem terdistribusi muncul kebutuhan yang lebih besar solusi untuk membantu dalam pengelolaan sistem terdistribusi. Terlepas dari kontribusi signifikan yang dilakukan terhadap pengembangan alat manajemen yang memantau dan mengendalikan sistem terdistribusi, sedikit yang telah dilakukan untuk mengatasi masalah seperti mengoptimalkan pelaksanaan fungsi manajemen sehubungan dengan sistem dan manajemen membutuhkan perbaikan.

Menurut Hall, (2002) bahwa untuk meningkatkan efesiensi dan efektivitas dalam penyalahgunaan narkoba dilakukan pengembangan pendekatan inovatif. 
JURNAL APLIKASI Manjemen \& Kewirausahaan MA SS A RO

Volume 1, No. 1, Pebruari 2019

Pendekatan inovatif ini dibahas dalam kontek bidang manajemen seperti manajemen kasus yang lebih luas-termasuk kasus sosial, kesehatan masyarakat, keperawatan, manajemen kasus modern, dan perawatan. Karena manajemen kasus telah didefinisikan dengan berbagai cara, membuat perbandingan program dan model menjadi sulit.

Milandru (2013), Setiap organisasi, mempertahankan eksistensinya dengan menggunakan Pendekatan terbaru ditingkat masing-masing organisasi, termasuk militer, meskipun ada beberapa perbedaan, mengarah kefungsi-fungsi berikut: pengorganisasian, koordinasi, pengarahan (pelatihan) dan pengendalian. Manajemen logistik di dalam struktur militer adalah proses yang berkelanjutan, sesuai dengan dimensinya, tetapi juga tergantung pada misi organisasi.

Travaillé, (2017) mengungkapkan bahwa ada disonansi yang cukup besar antara jumlah daerah di Polandia yang menyatakan kegunaan pengendalian manajemen dan pada saat yang sama dapat menunjukkan contoh tindakan nyata yang dilakukan untuk mengimplementasikannya.

Ignacy (2015), menemukan tidak adanya hubungan yang signifikan antara strategi yang digunakan perusahaan dengan pembangunan berkelanjutan (SD) dan misi instrumen pengendalian manajemen akan tetapi akan fokus pada pengukuran, pemantauan dan pelaopran kinerja ekonomi dan keuangan yang eksklusif.

\section{Rumusan Masalah}

Berdasarkan uraian pada latar belakang tersebut di atas maka menjadi masalah pokok adalah " penerapan manajemen diperlukan dalam persediaan pupuk bersubsisi ?

\section{KERANGKA TEORI}

\section{Pupuk Subsidi}

Pupuk bersubsidi adalah pupuk yang pengadaan dan penyalurannya ditataniagakan dengan HET serta ditetapkan di penyalur resmi di Lini IV.

Lini IV adalah lokasi gudang atau kios pengecer di wilayah kecamatan dan/atau desa yang ditunjuk atau ditetapkan oleh distributor (Peraturan Menteri Perdagangan Nomor 
JURNAL APLIKASI Manajemen \& Kewirausahaan MAAS SA RO

Volume 1, No. 1, Pebruari 2019

21/M-DAG/PER/6/2008 dan perubahannya melalui Permendag Nomor 07/M$\mathrm{DAG} / \mathrm{PER} / 2 / 2009)$

Petani adalah perorangan warga negara Indonesia yang mengusahakan budidaya tanaman pangan atau hortikultura dengan luasan tertentu. Pekebun adalah perorangan warga negara Indonesia yang mengusahakan budidaya tanaman perkebunan dengan luasan tertentu. Peternak adalah perorangan warga negara Indonesia yang mengusahakan budidaya tanaman hijauan pakan ternak dengan luasan tertentu. Pembudidaya ikan atau udang adalah perorangan warga negara Indonesia yang mengusahakan lahan, milik sendiri atau bukan, untuk budidaya ikan dan atau udang yang tidak memiliki izin usaha

Permentan Nomor 06/Permentan/SR.130/2/2011 mengatur tentang alokasi pupuk bersubsidi. Berikut kutipannya:

1. Alokasi pupuk bersubsidi dihitung sesuai dengan anjuran pemupukan berimbang spesifik lokasi dengan mempertimbangkan usulan kebutuhan yang diajukan Pemerintah Daerah Provinsi serta alokasi anggaran subsidi pupuk tahun 2011.

2. Alokasi pupuk bersubsidi tersebut dirinci menurut provinsi, jenis, jumlah, subsektor, dan sebaran bulanan. Alokasi tersebut dirinci lebih lanjut menurut kabupaten/kota yang ditetapkan dengan Peraturan Gubernur paling lambat ditetapkan pada awal bulan Maret 2011. Kemudian dirinci lebih lanjut menurut kecamatan yang ditetapkan dengan Peraturan Bupati/Wali Kota paling lambat akhir Maret 2011.

3. Alokasi pupuk bersubsidi tersebut memperhatikan usulan yang diajukan oleh petani, pekebun, peternak, pembudidaya ikan dan/atau udang berdasarkan RDKK (Rencana Definitif Kebutuhan Kelompok) yang disetujui oleh petugas teknis, penyuluh atau Kepala Cabang Dinas (KCD) setempat serta ketersediaan anggaran subsidi pupuk pada Tahun berjalan.

4. Dinas yang membidangi tanaman pangan, hortikultura, peternakan, perkebunan dan pembudidaya ikan dan/atau udang setempat wajib melaksanakan pembinaan kepada kelompok tani untuk menyusun RDKK sesuai luas areal usaha tani dan/atau kemampuan penyerapan pupuk di tingkat petani di wilayahnya. 
JURNAL APLIKASI Manajemen \& Kewirausahaan MAAS SA RO

Volume 1, No. 1, Pebruari 2019

5. Jika terjadi kekurangan alokasi kebutuhan pupuk bersubsidi di wilayah provinsi dan kabupaten/kota, dapat dipenuhi melalui realokasi antarwilayah, waktu dan subsektor. Realokasi antar provinsi ditetapkan lebih lanjut oleh Dirjen Tanaman Pangan, realokasi antar kabupaten/kota ditetapkan oleh Gubernur, dan realokasi antarkecamatan ditetapkan oleh Bupati/Wali Kota.

6. Untuk memenuhi kebutuhan petani, realokasi tersebut dapat dilaksanakan terlebih dahulu sebelum penetapan dari Gubernur dan/atau Bupati/Wali Kota berdasarkan rekomendasi dari Dinas Pertanian setempat.

7. Apabila alokasi pupuk bersubsidi di suatu provinsi, kabupaten/kota, kecamatan pada bulan berjalan tidak mencukupi, produsen dapat menyalurkan alokasi pupuk bersubsidi di wilayah bersangkutan dari sisa alokasi bulan-bulan sebelumnya dan/atau dari alokasi bulan berikutnya sepanjang tidak melampaui alokasi 1 (satu) tahun.

\section{Pegertian dan Peranan Pengendalian Persedian}

Pengendalian persediaan merupakan salah kegiatan yang berbubungan erat satu sama dalam kegiatan proses produksi di samping persediaan juga mempunyai pengaruh yang menentukan terhadap bagian-bagian yang ada pada suatu perusahaan.

Menurut Jones and George (2012) mengenai pengertian pengendalian (controlling) ini, Pengendalian adalah proses dimana para manajer memantau dan mengatur bagaimana sebuah organisasi dan segenap anggotanya menjalankan kegiatan yang diperlukan untuk mencapai tujuan organisasi secara efisien dan efektif. Dalam pengendalian, para manajer memantau dan mengevaluasi apakah strategi dan struktur organisasi bekerja seperti yang dikehendaki, bagaimana hal-hal tersebut dapat ditingkatkan dan bagaimana harus diubah jika tidak bekerja.

Itulah sebabnya sehingga setiap perusahaan akan selalu diperhadapkan pada masalah pengendalian persediaan. Pengendalian yang tidak efektif dan efisien akan menimbulkan masalah bagi perusahaan terhadap pelayanan pada konsumen, karena mungkin pada suatu saat konsumen memerlukan brang tetapi tidak tersedia dipasaran. Apabila hal ini terjadi, maka akan menimbulkan efek bagai perusahaan karena perlu 
JURNAL APLIKASI Manjemen \& Kewirausahaan MA SS A RO

Volume 1, No. 1, Pebruari 2019

para langganan/konsumen dapat pindah ke perusahaan lain yang ruenghasilkan yang sejenis.

Menurut Sofyan Assauri (1987:185) mendefinisikan pengendalian persediaan adalah sebagai suatu kegiatan untuk menentukan tingkat dan komposisi daripada persediaan parts bahan baku dan barang jadi/produk, sehlngga perusahaan dapat melindungi kelancaran produksi dan penjualan serta kebutuhan-kebutuhan pembelanjaan perusahaan dengan efektif dan efisien.

Dari pelaksanaan kegiatan pengendalian persediaan yang optimal atau ekonomis, maka berikut ini akan diuraikan pengertiaan persediaan optimum, recorder point dan persediaan pengaman.

\section{Persediaan Optimum}

Sebagaimana yang telah dijelask.an terdahulu bahwa pengendalian persediaan dalah merupakan suatu pengaturan persediaan . yang ditujukan untuk mencapai tingkat pelayanan sebaik-baiknya dengan biaya seminimal mungkin. Sasaran ini disebut persediaan optimal.

\section{Reorder Point}

Agat tingkat persediaan yang optimal tercapai, diperlukan adanya pertimbangan berkenaan dengan besarnya volume pemesanan mengisi persediaan, kapan sebaiknya tersebut dilakukakn dar. sampai beberapa jauh diciptakan persediaan pengaman.

\section{Persediaan Pengaman (safety stock/buffer stock)}

Untuk setiap situasi ada suatu tenggang waktu antara menetapkan pesanan untuk menggatikan persediaan dan penerimaan dari barang yang masuk kedalam persediaan. Tenggang waktu tersebut biasanya disebut "Delivery Lead Time".

\section{Hipotesis}

Berdasarkan rumusan masalah yang diajukan, maka hipotesis adalah : “diperlukan penerapan manajemen sehingga penyaluran pupuk subsidi secara efektif dan efisien". 
JURNAL APLIKASI Manajemen \& Kewirausahaan MAAS A RO

Volume 1, No. 1, Pebruari 2019

\section{METODE PENELITIAN}

\section{Metode Analisis}

Alat analisa ini digunakan untuk penerapan manajemen persediaan pupuk subsidi yang dinyatakan dalam bentuk persamaan matematik. Langkah dalam analisa regresi berganda adalah dengan menentukan persamaan garis regresi berganda dengan rumus sebagai berikut :

$$
\mathrm{Y}=\mathrm{a}+\mathrm{b}_{1} \mathrm{X}_{1}+\mathrm{b}_{2} \mathrm{X}_{2}+\mathrm{b}_{3} \mathrm{X}_{3}+\mu
$$

Keterangan :

$$
\begin{array}{ll}
\mathrm{Y} & =\text { Pengendalian Manajemen } \\
\mathrm{X}_{1} & =\text { Perencanaan } \\
\mathrm{X}_{2} & =\text { pengorganisasian } \\
\mathrm{X}_{3} & =\text { Aktivitas } \\
\mu & =\text { Error dalam penelitian } \\
\mathrm{a} & =\text { Bilangan konstant }
\end{array}
$$

\section{PEMBAHASAN}

Analisis ini digunakan untuk mengetahui atau meramalkan besarnya perencanaan, pengorganisasian, dan aktivitas pada pengendalian manajemen. Hasil pengolahan data dengan bantuan komputer program SPSS versi 10,0 didapatkan persamaan regresi: $\mathrm{Y}=0,196+0,201 \mathrm{X}_{1}+0,352 \mathrm{X}_{2}+0,443 \mathrm{X}_{3}$. Hasil dari analisis tersebut dapat diinterpretasikan sebagai berikut:

$\mathrm{a}=0,196$, artinya bahwa apabila variabel perencanaan, pengorganisasioan, dan aktivitas sama dengan nol maka pengendalian manajemen sebesar 0,196 satuan.

$\mathrm{b}_{1}=0,201$, artinya bahwa apabila perusahaan memperhatikan variabel perencanaan $\left(\mathrm{X}_{1}\right)$, maka pengendalian manajemen akan naik sebesar 0,201 satuan, sedangkan variabel yang lain konstan.

$\mathrm{b}_{2}=0,352$, artinya bahwa apabila karyawan memperhatikan variabel pengorganisasian $\left(\mathrm{X}_{2}\right)$, maka pengendalian manajemen akan naik sebesar 0,352 satuan, sedangkan variabel yang lain konstan. 
$\mathrm{b}_{3}=0,443$, artinya bahwa apabila perusahaan memperhatikan variabel aktivitas $\left(\mathrm{X}_{3}\right)$, maka pengendalian manajemen akan naik sebesar 0,443 satuan, sedangkan variabel yang lain konstan

\section{Uji Hipotesis}

\section{a. Uji t}

Berdasarkan hasil analisis dapat diketahui hasil uji t seperti tampak pada tabel 1. berikut:

Tabel 1. Rekapitulasi hasil uji t

\begin{tabular}{|c|c|c|c|}
\hline Variabel & $t_{\text {hitung }}$ & $t_{\text {tabel }}$ & Sig. \\
\hline Perencanaan $\quad\left(\mathrm{X}_{1}\right)$ & 2,641 & 1,990 & 0,010 \\
\hline Pengorganisasian $\left(\mathrm{X}_{2}\right)$ & 4,166 & 1,990 & 0,000 \\
\hline Aktivitas & 5,609 & 1,990 & 0,000 \\
\hline
\end{tabular}

Sumber: Data yang diolah

\section{a. Uji F}

Karena $\mathrm{F}_{\text {hitung }}>\mathrm{F}_{\text {tabel }} ; 34,057>2,720$ dan nilai sign. $0,000<0,05$ maka Ho ditolak dan $\mathrm{H}_{\mathrm{a}}$ diterima, hal ini berarti variabel Perencanaan, Pengorganisasian, dan Aktivitas berpengaruh secara serentak (simultan) dan signifikan pada pengendalian manajemen.

\section{b. $\mathbf{U j i} \mathbf{R}^{2}$}

Hasil perhitungan untuk nilai $\mathrm{R}^{2}$ diperoleh dalam analisis regresi berganda diperoleh angka koefisien determinasi atau $\mathrm{R}^{2}$ sebesar 0,516, artinya bahwa $51,60 \%$ variasi variabel pengendalian manajemen dapat dijelaskan oleh variabel perencanaan, pengorganisasian, dan aktivitas sedangkan sisanya yaitu 48,40\% tidak dijelaskan oleh variabel yang tidak diteliti. 
JURNAL APLIKASI Manajemen \& Kewirausahaan MASS A RO

Volume 1, No. 1, Pebruari 2019

\section{PENUTUP}

\section{Kesimpulan}

Berdasarkan analisis dan pembahasan yang telah dilakukan pada pembahasan sebelumnya, maka dapat ditarik kesimpulan sebagai berikut:

1. Berdasarkan hasil analisis regresi dapat diketahui persamaannya bahwa: Y $=0,196+0,201 X_{1}+0,352 X_{2}+0,443 X_{3}$, artinya bahwa variabel Perencanaan, Pengorganisasian, dan Aktivitas mempunyai pengaruh yang positif terhadap pengendalian manajemen

2. Berdasarkan hasil analisis uji $t$, didapatkan nilai $t_{\text {hitung }}$ untuk perencanaan sebesar 2,641 $>\mathrm{t}_{\text {tabel }}(1,990)$, variabel pengorganisasian didapatkan $\mathrm{t}_{\text {hitung }}$ $(4,166)>t_{\text {tabel }}(1,990)$, dan variabel aktivitas didapatkan $t_{\text {hitung }}(5,609)>$ tabel (1,990), artinya semakin baik Perencanaan, Pengorganisasian, dan Aktivitas yang diberikan maka semakin baik dan naik pula pengendalian manajemen tersebut, dan variabel aktivitas merupakan faktor yang dominan pengaruhnya. Hasil uji $\mathrm{t}$ tersebut membuktikan bahwa hipotesis kedua $\left(\mathrm{Ha}_{2}\right)$ terbukti kebenarannya.

3. Hasil uji $\mathrm{F}$ diperoleh $\mathrm{F}_{\text {hitung }}>\mathrm{F}_{\text {tabel }} ; 34,057>2,170$ maka Ho ditolak dan $\mathrm{H}_{\mathrm{a}}$ diterima. Hal ini berarti ada pengaruh yang signifikan antara variabel perencanaan, pengorganisasian, dan aktivitas terhadap variabel pengendalian manajemen secara simultan. Berarti hipotesis pertama $\left(\mathrm{Ha}_{1}\right)$ terbukti kebenarannya.

4. Analisis koefisien determinasi diperoleh angka koefisien determinasi atau $\mathrm{R}^{2}$ sebesar 0,516, artinya bahwa $51,60 \%$ variasi variabel pengendalian manajemen dapat dijelaskan oleh variabel perencanaan, pengorganisasian, dan aktivitas sedangkan sisanya yaitu $48,40 \%$ tidak dijelaskan dalam penelitian ini.

\section{Saran}

Diharapkan kepada pemerintah untuk melanjutkan kebijakan subsidi pupuk dan perlu tetap dipertahankan karena masih diperlukan untuk peningkatan produktivitas usaha tani dan membantu rakyat kecil. Hendaknya pemerintah juga 
JURNAL APLIKASI Manjemen \& Kewirausahaan MA SS A RO

Volume 1, No. 1, Pebruari 2019

mencukupi kebutuhan pupuk terutama di awal masa tanam sehingga tidak terjadi kelangkaan yang mengakibatkan harga pupuk naik. Kepada penjual dan distributor hendaknya menghindari hal-hal yang dilarang. Kepada petani hendaknya menggunakan pupuk dengan tepat jenis, tepat waktu dan tepat dosis serta menghindari pemborosan dan mengakibatkan kelangkaan pupuk akibat tingginya permintaan pupuk.

\section{DAFTRA PUSTAKA}

Abdu, H. L., Hanan;Bauer, Michael A (2002). "Optimizing Management Functions in Distributed Systems." Journal of Network and Systems Management 10(4): 505.

Assauri Sofyan. 1980. Manajemen Produksi. Penerbit LPPE Universitas Indonesia. Jakarta

Chase, Richard B. 1985 . Production Operation Manajemen. Second Edition, Home Wrocl : Iliinoris, Richard D. Irwin, Inc.

George, Jennifer and Gareth R Jones. (2012). Understanding and Managing Organizational Behavior. Pearson Education, Inc, New Jersey

Hall, J. A. C., Christopher;Walsh, Elizabeth;Huber, Diane L;Jampoler, Jennifer S (2002). "Iowa case management: Innovative social casework." National Association of Social Workers, Inc 2(47): 132

Ignacy, J. a. (2015). "THE SIGNIFICANCE OF MANAGEMENT CONTROL IN THE CONCEPT OF NEW PUBLIC MANAGEMENT - SELECTED THEORETICAL AND PRACTICAL ASPECTS IN POLISH LOCAL GOVERNMENT UNITS.pdf." International Journal of Arts \& Sciences 4.

Milandru, M. (2013). "RECOGNITIONS RELATED TO LOGISTICS MANAGEMENT IN MILITARY ORGANIZATION DURING PEACE TIME." Management and Economics 2(3): 14

Nancy W. eder, P. (2002). "Care Management as Management." Springer Publishing Travaillé, D. and G. Naro (2017). "Management control facing the challenges of overall performance." Society and Business Review 12(2): 175-199

Peraturan yang terkait pupuk subsidi : Badan Pusat Statistik. 2010. Data Strategis BPS.

Republik Indonesia. 2011. Peraturan Menteri Pertanian tentang No. 06 tentang Kebutuhan dan Harga Eceran Tertinggi (HET) Pupuk Bersubsidi untuk Sektor Pertanian Tahun Anggaran 2011

Republik Indonesia. 2010. Undang-Undang Nomor 10 Tahun 2010 tentang Anggaran Pendapatan dan Belanja Negara (APBN) Tahun Anggaran 2011. 
Republik Indonesia. 2010. Peraturan Menteri Keuangan No 120 Tahun 2010 tentang Tata Cara Penyediaan Anggaran, Penghitungan, Pembayaran, dan Pertanggung jawaban Subsidi Pupuk

Republik Indonesia. 2009. Peraturan Menteri Perdangan No.07 Tahun 2009 tentang Perubahan atas Peraturan Menteri Perdagangan

Republik Indonesia Nomor 21/M-DAG/PER/6/2008 tentang Pengadaan dan Penyaluran Pupuk Bersubsidi

Republik Indonesia. 2008. Peraturan Menteri Perdagangan No.21 Tahun 2008 tentang Pengadaan dan Penyaluran Pupuk Bersubsidi untuk Sektor Pertanian

Republik Indonesia. 2005. Peraturan Presiden Tahun 2005 tentang Penetapan Pupuk Bersubsidi sebagai Barang dalam Pengawasan

Republik Indonesia. 2003. Peraturan menteri Negara BUMN No.183 tentang Komponen Harga Pokok Penjualan Pupuk Bersubsidi. 